\title{
The Analysis of Differences in Hospital Rill Rates and INA- CBG's Rate on Sectio Caesare Action in RSU. Imelda Pekerja Indonesia Medan 2019
}

\author{
Marta Simanjuntak ${ }^{1}$, Destanul Aulia $^{2}$, Zulfendri $^{3}$ \\ 1,2,5University of Sumatera, Indonesia \\ Email: mmartasimanjuntak@gmail.com
}

\begin{abstract}
:
The Indonesian government has developed a Health Insurance program National Social Security Administering Bodies (BPJS) Health. One of the ways to pay for health services for hospitals in Era JKN is the Indonesian Case Base Groups (INA-CBG's) payment system, namely the amount of claim payment by BPJS Health to the hospital for the package services based on diagnosis of disease and procedures. This study aims to analyze hospital real rates and INA CBG rates on the action of sectio caesarea and to find out the efforts made hospitals to cover INA-CBG's shortfall in claims costs. Types of research Qualitative descriptive conducted by in-depth interviews. Research sites at the hospital. Imelda Indonesian Worker having his address at Bilal Street No. 24 Kelurahan Pulo Brayan Darat I, East Medan District. The research was carried out since months January 2019 until finished. The population in this study is claim data delivery of inpatients who performed sectio casearea at month March and April as many as 143 cases The samples in this study were all population of 143 cases. The results showed that the difference in real rates hospital and INA-CBG rates on Sectio Caesaria at RSU. Imelda Worker Indonesia Medan in 2019 amounted to $73 \%$ of the real hospital rates exceeding the tariff INA-CBG's with a total difference in costs reaching IDR 199,661,028. And $39 \%$ real hospital fee less than INA-CBG's package rate. Efforts are conducted by the RSU. Imelda Indonesian workers to cover the shortage of costs INA-CBG's claims include using students who come from schools Imelda's own foundation, set the Sectio Caesare service package on general patients and providing supporting facilities. Suggested to RSU. Imelda Indonesian workers evaluate the financial risks received from services Sectio Caesare and evaluating the distribution of INA-CBG's claim costs for services Sectio Caesare is up to standard.
\end{abstract}

Keywords:

sectio caesare; hospital real rates; INA-CBG's rates

\section{Introduction}

Every country has health insurance for the community for the purpose of community welfare. As with Singapore they have a health system philosophy with 3M (Medisave, medishield, and medifund). Medisave is a national health insurance where everyone saves money for their health needs, saved from 7-9 percent of the monthly salary and from the company also contributes 13 percent.

Medishield is to support Medisave to help members meet Class B2 / C or if there is large hospitalization bills while Medifund is like an eternal reserve fund prepared by the Singapore government for Singaporeans who cannot afford to pay hospital bills (Yui 2012) 
To overcome this, the 58th World Health Assembly (WHA) 2005 in Geneva encourages every country to develop Universal Health Coverage (UHC) or universal health coverage for all its residents. So the Indonesian government implements it through the Health Insurance Program or National Health Insurance (JKN) (Permenkes, 2014).

For the implementation of the National Social Security System, a Social Security Administering Body (BPJS) was formed to implement the Social Security program throughout Indonesia. The BPJS was formed into 2 (two), namely BPJS Health and BPJS Ketenagakerjaan. BPJS Kesehatan administers a health insurance program and BPJS Ketenagakerjaan provides work accident insurance, old age savings, pension benefits, and death benefits (Law, 2011).

In the context of implementing Health Insurance in the National Social Security System, the rates for health services at first-level health facilities and advanced level health facilities is determined using the Indonesian Case Base Groups (INA-CBG's) payment pattern (Permenkes, 2014).

The hospital as an advanced level referral health facility is an important component for health service providers and providers in the implementation of the JKN program. The JKN program is part of public policy as a result of the government's good will. The success of government programs in JKN, among others, depends on the extent to which this policy is implemented in hospitals (Thabrany, 2014).

Private hospital rates are set by the head of the hospital or the hospital director with the approval of the hospital owner (Permenkes, 2015).

In Indonesia, in general, the number of cesarean deliveries in government hospitals is around $20-25 \%$ of total deliveries, while for private hospitals the number is very high, which is around $30-80 \%$ of total deliveries (Rosyid, 2009).

The Executive Board of the Indonesian Doctors' Association together with the Government (Ministry of Health and Social Welfare Department) issued a Circular of the Directorate General of Medical Services (Dirjen Yanmedik) of the Ministry of Health of the Republic of Indonesia which states that the rate of sectio caesaria for teaching or referral hospitals is $20 \%$ and private hospitals $15 \%$ (Kasdu, 2003).

Based on the assumptions of various parties related to the increasing tendency of childbirth with cesarean section, this is caused by feelings of anxiety and fear of facing pain, not being strong to withstand pain during spontaneous labor, fear of not being able to bear down on straining, trauma in past labor, trust the date and time of birth that can affect the fate of the child in the future, worried that vaginal delivery will damage sexual relations, and confidence.

Word Health Organization(WHO) considers the rate of caesarean section measures to range from $5 \%$ to $15 \%$ of the maximum range targeted for life-saving interventions for delivery. The rate of delivery by Caesarean section in Indonesia is quite high, reaching $70 \%$ (WHO, 2016).

Results of Riskesdas 2018, To determine strategic policies (RPJMN, Renstra) and program planning, data on health status and its determinants are required to be measured in the community., and shows births in the last five years $66.7 \%$ with Sectio Caesarea in 
Indonesia reaching 9.8\% with the highest proportion in DKI Jakarta $(19.9 \%)$ and the lowest in Southeast Sulawesi (3.3\%). For North Sumatra, the birth of Sectio Caesarea is the highest proportion, reaching around $13.8 \%$ after East Java, which is around 13\%.

Based on the research of Kusumaningtyas, et al (2013), the case of childbirth with Sectio Caesarea in the Jamkesmas program has a difference between the real costs of IDR 68,774,173 which is greater than the INA CBG's rate of IDR 9,605.29.

\section{Review of Literatures}

\subsection{BPJS Kesehatan (Social Security Administering Bodies)}

Health insurance is a guarantee in the form of health protection so that participants receive health care benefits and protection in meeting basic health needs that is given to every person who has paid dues or whose contributions have been paid by the government. The Social Security Administering Body (BPJS) for Health is a legal entity established to administer a health insurance program (Depkes RI, 2012).

The benefits of BPJS Health Insurance are first level health services, namely nonspecialized health services including:
a. Service Administration
b. Promotional and preventive services
c. Examination, medication, medical consultation
d. Non-specialized medical action, both operative and non-operative
e. Medicines and consumable medical materials services
f. Blood transfusion according to medical needs
g. First level laboratory diagnostic investigations

Social Security Administering Bodies (BPJS) In accordance with Law of the Republic of Indonesia Number 24 of 2011 concerning Social Security Administering Bodies, Social Security Administering Bodies, hereinafter abbreviated as BPJS, are legal entitie s established to administer social security programs. BPJS aims to realize the implementation of the guarantee of the fulfillment of the basic needs of a decent life for each Participant and / or their family members.

\subsection{Definition of INA-CBG's}

Case Base Groups (CBG's) basically has the same definition as DRG which is also included in the casemix system. Indonesia Case Based Groups (INA-CBG's) are CBG's associated with rates calculated based on costing data in Indonesia and run using the United Nation University Grouper (UNU-GROUPER), in contrast to the previous INA-DRG which used the commercial grouper system from PT. 3M Indonesia. UNU is an institution under the United Nations with the priority of helping developing countries to achieve the Millennium Development Goals (MDG's) (Depkes RI, 2011).

The calculation of the cost of care in this system is carried out based on the patient's final diagnosis while being hospitalized. The application of case-based groups of payments based on the average cost spent by several hospitals for a diagnosis, the amount of the cost of treating patients with a diagnosis will be different if the type of hospital is different (Tabrany, 2008).

The case based groups payment system is based on the diagnosis of patients out of care. The hospital is reimbursed for treatment based on the average cost spent by the hospital 
in the management of a disease diagnosis. The INA-CBG's system (Indonesia Case Based Groups) is a solution for controlling health service costs because it relates to quality, equity, coverage in the health system which is one of the elements in health spending and payment mechanisms for mixed case-based patients (Kemenkes RI, 2010).

\subsection{Definition of Indonesian Case Based Groups (INA CBG's)}

Indonesia Case Based Groups (INA CBG's) mis a casemix system implemented in Indonesia. The basis for grouping in the INA-CBG's uses a codification system of the final diagnosis and actions / procedures that become service outputs, with references (Permenkes, 2016):

ICD-10 for diagnosis.

a. ICD-9-CM for action / procedure.

b. The two ICDs were grouped using an information technology system in the form of the INA CBG application, resulting in 1,077 groups / case groups consisting of 789 groups of inpatient cases and 288 groups of outpatient cases.

c. Diagnosis codes and procedures are grouped using the UNU grouper (UNU Grouper). UNU-Grouper is a casemix Grouper developed by United Nations University (UNU).

\subsection{INA CBG's Rates}

The INA-CBG rates is a package rate that includes all components of hospital resources used in both medical and non-medical services. INA-CBG's rates include (Permenkes, 2013):

a. The cost of health services provided by class A, class B, class C and class D hospitals in regional 1.

b. Rates for health services provided by class A, class B, class C and class D hospitals in regional 2.

c. Rates for health services provided by class A, class B, class C and class D hospitals in regional 3.

d. Rates for health services provided by class A, class B, class C and class D hospitals in regional 4.

e. Rates for health services provided by class A, class B, class C and class D hospitals in regional 5.

f. Rates for health services provided by national referral public hospitals.

g. Rates for health services provided by national referral special hospitals.

\subsection{Hospital Service Rates}

Hospital Service Rates Rates is the value of a service which is determined by the size of an amount of money based on the consideration that with this value a hospital is willing to provide services to patients. Hospital rates are an aspect that is very concerned about by private hospitals as well as by government-owned hospitals.

For government hospitals, rates are determined based on the Decree of the Minister of Health or Local Government. This shows the tight control of the government as the owner of the hospital (Trisnantoro, 2009 in Hotma 2015).

\section{a. Purpose of Rates Determination}

The handling of rates setting and the purpose of the determination is influenced by the owner. Against this ownership background, rates can be set for the following purposes: 
1. Rates Setting for Cost Recovery.

This situation is mainly found in government hospitals whose subsidies are decreasing over time.

2. Rates Setting for Cross Subsidies.

The existence of a policy so that a strong economic community can help ease the financing of hospital services for economically weak communities.

3. Rates Setting to Improve Service Access.

The policy to set the lowest possible rate so that it is hoped that with this low rate, access will be good or easy, especially for the poor.

4. Rates Setting to Improve Service Quality.

The rates setting policy on VIP wards is based on considerations to improve service quality and also increase work satisfaction of specialist doctors.

5. Rates Setting to Reduce Competitors.

Can be done to prevent new hospitals that will become competitors.

6. Rates Setting to Increase Profits.

Can be done in the hospital market which tends to be controlled by one hospital (monopoly) with the aim of maximizing revenue.

7. Rates setting aimed at minimizing the use of services, reducing usage, the ratess are set high.

8. Rates Determination with the Purpose of Creating a Corporate Image Creating a Corporate Image is the setting of ratess with the aim of enhancing the image of the Hospital.

\section{b. Rates Policy}

a) Hospital service rates are determined by taking into account the value of hospital services as well as the ability to pay the local community.

b) Hospital rates are determined on the basis of the type of service, level of sophistication of service and class of care.

c) The provision of relief or exemption from hospital service fees for underprivileged patients is regulated by the director of the hospital concerned based on the provisions stipulated by the Director General of Medical Services.

d) Hospital rates for community groups whose payment is made by the guarantor through a written agreement.

e) Determination of the amount of the hospital service rates is carried out by considering the existence of cross subsidies for class III patient service rates. (Decree of the Minister of Health of the Republic of Indonesia Number 1165 / MENKES / SK / X / 2007 concerning the Pattern of Public Service Agency Hospital Rates).

\section{c. Rates Fixing Strategy}

1) Cost-oriented Rates setting Namely the determination of the rate / price which fully refers to the costs incurred, both marginal costs and total costs including indirect costs (overhead cost).

2) Determination of Ratess Based on demand. The hospital takes into account the conditions of demand, not the level of costs, in determining the rate / price. 
3) Competition-oriented Rates Determination Hospitals determine rates / prices on the basis of ratess / prices set by its competitors.

\section{Research Methods}

This type of research is carried out by qualitative descriptive analysis which aims to describe the real cost of the hospital with the INA-CBG's rate of sectio caesarean action at the hospital. Imelda Pekerja Indonesia. The location of this research is in the Imelda Hospital Worker Indonesia, which is located at Jalan Bilal No. 24 Kelurahan Pulo Brayan Darat I, East Medan District, which is a Class B hospital with an intermediate level of accreditation. The reason for choosing the research location was because according to researchers, the Pekerja Indonesia Imelda Hospital was a suitable and young place to be reached by researchers.

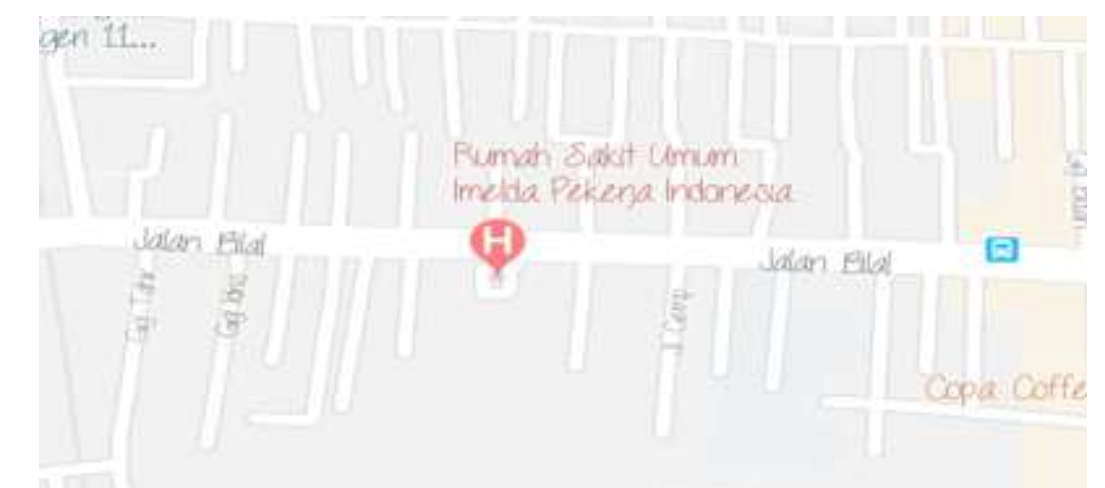

Figure 1. Plan of Hospital Location. Imelda Medan Pekerja Indonesia

\section{Discussion}

\subsection{Determination of RSU Real Rates. Imelda Pekerja Indonesia}

The research results obtained information on the hospital. Imelda Kerja Indonesia, that the real hospital rate is calculated from the unit price, per details of the type of service after taking action, for the standard hospital tariff has been determined in the policy regulation of the Director of RSU Imelda Kerja Indonesia and known by the owner of the foundation.The financing at the Imelda Hospital for Workers in Indonesia uses the FFS (Fee For Service) payment system with the help of the biling system to calculate all costs and the amount of fees that must be paid by the patient or the payer determined after the service is provided.

Inpatient care at the Pekerja Indonesia Imelda Hospital, patients who perform sectio caesarea will receive supporting examination services in the form of ultrasound and laboratory examinations. Meanwhile, the medical service uses generic drugs. Procedures in the care and treatment of patients have implemented the Clinical Pathway as a means to treat each patient so that there is no diversity of actions for one type of diagnosis. The clinical pathway can also control when the patient has to go home, so that the length of stay or length of stay of the patient can be controlled.

Details of real rates for Caesarean section actions at RSU. Imelda, Pekerja Indonesia, among others: Honor for Operation Operation Doctor for Caesarean Section at Class I Unit Cost of Rp. 3,000,000, for class II the amount of Rp. 2,200,000, for class III as much as Rp. 1. 200,000. Fees for the anesthetist for cesarean section. Unit Cost for class I is Rp. 1,000,000, for class II as much as Rp. 700,000, for class III of Rp. 500,000. Anesthesiologist assistant services Unit Cost class I of Rp. 500,000, for class II the amount of Rp. 400,000, in class III of 
Rp. 300,000. CTG Unit Cost for class I of Rp. 100,000, in class II as much as Rp. 100,000, in class III of Rp. 100,000. Rent Ok action SC Unit Cost class I of Rp. 1,200,000, for class II the amount of Rp. 1,000,000, in class III of Rp. 800,000, Doctor Visit Consultation Sp.SPOG Class I Unit Cost of Rp. 160. 000, in class II the amount of Rp. 130,000, in class III of Rp. 100,000, General Physician Consultation Unit Cost for class I is Rp. 120,000, in class II is Rp. 100,000, in class III of Rp. 80,000, Urine catheter installation Class I Unit Cost of Rp. Rp. 150,000, for class II the amount of Rp. 150,000, for class III as much as Rp. 150,000, Installation of Infu (IGD) Unit Cost for class I of Rp. 150,000, for class II the amount of Rp. 150,000, in class III of Rp. 150,000, Revision / Replace small and medium Verban Unit Cost for class I of Rp. 250,000, in class II Rp. 250,000, in class III Rp. 250,000, Routine Blood Laboratory Unit Cost class I of Rp. 70,000, for class II as much as Rp. 70,000, in class III of Rp. 70,000, class I Hemoglobin Unit Cost of Rp. 250,000, in class II as much as Rp. 250,000. in class III of Rp. 250,000, Class I HbsAg Rapid Unit Cost of Rp. 70,000, for class II as much as Rp. 70,000, in class III of Rp. 70,000, Free HIV examination (Rapid test method), Class I Administration Unit Cost Rp. 200,000, class II Rp. 160,000, class III Rp. 80,000, Class I Pink Bracelet Unit Cost Rp. 10,000, in class II, amounting to IDR 10,000, in class III IDR 10,000, Unit Cost Class I room rental of IDR 600. 000, in class II the amount of Rp. 400,000, in class III the amount of Rp. 250,000, the unit cost drug for class I is Rp. 635. 000, in class II the amount of Rp. 547,800, in class III of Rp. 530,700, ALKes Unit Cost in class I is Rp. 633,000, in class II is Rp. 434,500, in class III is Rp. 351,400, Class I BMHP Unit Cost of Rp. 144,000, for class II as much as Rp. 142,000, in class III of Rp. 106,000, the total real hospital tariff for sectio caesarean section is in class I of Rp. 11,032,200, for class II as much as Rp. 8,594,300, in class III of Rp. 6,318,100, and while the INA-CBG's rate, the sectio caesarean section is in the category of mild severity (I) of Rp. 8,465,700, while (II) is Rp. 7,065,200, at weight (III) of Rp. 5,406,900.

This is in accordance with PERMENKES No. 85 of 2015, hospital rates that are managed by the private sector are set by the head of the hospital or the hospital director with the approval of the hospital owner, so that every examination and action will be charged according to the rate at the hospital. Rates are determined after service is performed.

The results of the study were based on patient data entering and leaving patients with sectio caesare treatment at the hospital. Imelda, Pekerja Indonesia from March to April 2019 as many as 149 patients with a total real cost of Rp. 1,210,233,377.

Based on the diagnosis data of patients with sectio caesare action, it shows that the most patients diagnosed with pre-eclampsia were 74 patients $(50 \%)$, while the few diagnoses experienced by patients with Latitude were 28 (19\%), patients.

Inpatient care services at the Imelda Hospital Worker Indonesia, patients who perform sectio caesarea will receive supporting examination services in the form of ultrasound, laboratory examinations, anesthesia procedures, cesarean surgery. Meanwhile, the medical service uses generic drugs. Procedures in the care and treatment of patients have implemented the Clinical Pathway as a means to treat each patient so that there is no diversity of actions for one type of diagnosis. The clinical pathway can also control when the patient has to go home, so that the length of stay or length of stay of the patient can be controlled.

\subsection{RatesINA-CBG's RSU. Imelda Pekerja Indonesia}

Based on the results of research at the Pekerja Indonesia Imelda Hospital, BPJS claims that use the INA CBG's 5.2 software for cases of caesarean section delivery are divided into 3 (three) categories, namely Mild Caesarean Surgery (Caesarean section) with code O-6-10-I, 
Moderate Caesarean Surgery (Sectio Caesarea) Procedure with code O-6-10-II and Heavy Caesarean Surgical Procedure (Sectio Caesarea) with code O-6-10-III. While the code of action for sectio caesarea is 74.99 (Other caesarean section of unspecified type).

This is in accordance with PERMENKES No. 76/2016 on Guidelines for Indonesian Case Base Groups (INA-CBG) in the Implementation of National Health Insurance, tariff claims on INA CBG's use tools in the form of INA CBG's 5.2 software that has been determined by the Ministry of Health, so that the tariff output is appropriate. with predefined databases. In addition, this service rate is also adjusted to the severity of the patient's illness while being treated in the general and special hospital treatment rooms.

INA-CBG's package rates for the payment of BPJS claims for patients with Caesarean section treatment at the Imelda Hospital for Workers in Indonesia, based on the regionalization list. The Pekerja Indonesia Imelda Hospital is located in regional 3 namelyNorth Sumatra Province. The calculation of INA-CBG's rates is based on packages, namely the incorporation of diagnostic codes and procedure codes for actions in an INACBG's code whose tariff standard has been set by the Government of Indonesia.

INA-CBG's tariff for sectio caesarean section with a diagnostic category Delivery by elective caesarean section (due to CPD or Cepalo Pelvic Disproportion), and the O-6-10-I severity code in class 3 is IDR 5,406,900, class 2 is IDR. 7,065,200, class 1 as much as Rp. $8,465,700$, diagnostic category Delivery by elective caesarean section (due to latitude) and the O-6-10-II severity code in class 3 as much as Rp. Rp. 6,295,600, class 2 as much as Rp. 7,965,900, class 1 as much as Rp. 9,055,300, in the diagnostic category Delivery by emergency section (caused by pre-eclampsia) and and the O-6-10-III severity code in class 3 as much as Rp. 8,470,100, in class 2 as much as Rp. class 1 as much as Rp. 10,958,240.

Based on the calculation results, it is known that the total hospital rates issued for services to BPJS patients with sectio caesarean treatment at the RSU. Imelda, Pekerja Indonesia from March to April 2019 as many as 149 patients with a total INA-CBG's cost of Rp. 928,230,740.

Based on the analysis results obtained information that there is a total difference between the real hospital rates and the INA-CBG package rates in the payment of BPJS claims for patients with Caesarean section treatment in the period March to April 2019 as much as Among the 149 patients, the cost incurred by the hospital was Rp. 1,210,233,377, while the cost incurred by INA-CBG's is Rp. 928,230,740. The difference between hospital rates and INA-CBG's rates is Rp. 282,002,637, the difference is negative because the total cost of services incurred by the hospital for sectio caesarean is greater than the total cost of INACBG's paid by BPJS Kesehatan.

Based on the results of the calculation of the total difference from the real hospital rates with the INA-CBG's rates in the category of care class and the severity of the Caesarean section cases at the hospital. Imelda, an Pekerja Indonesia, for grade 1 in the case of Delivery by elective caesarean section (due to CPD or Cepalo Pelvic Disproportion) the total difference is Rp. $1,806,500$, in the case of Delivery by elective caesarean section (due to latitude) the total difference is Rp. 1,664,100, in the case of Delivery by emergency section (due to preeclampsia) the total difference was Rp. 1,378,690.

The total difference between the real hospital rates and the INA-CBG's rates in the category of care class and the severity of cesarean section cases at the hospital. Imelda Pekerja 
Indonesia, for grade 2 In the case of Delivery by elective caesarean section (due to CPD or Cepalo Pelvic Disproportion) the total difference is Rp. 1,209,300, in the case of Delivery by elective caesarean section (due to latitude) the total difference is Rp. 1,090,000, in the case of Delivery by emergency section (due to pre-eclampsia) the total difference is Rp. 1,811,000.

The total difference between the real hospital rates and the INA-CBG's rates in the category of care class and the severity of cesarean section cases at the hospital. Imelda Pekerja Indonesia, for grade 3 In the case of Delivery by elective caesarean section (due to CPD or Cepalo Pelvic Disproportion) the total difference is Rp. 901,200, in the case of Delivery by elective caesarean section (due to latitude) the total difference is $\mathrm{Rp} .768,745$, in the case of Delivery by emergency section (due to pre-eclampsia) the total difference is Rp. 564,900.

The results of this study are similar to Agustin's (2011) study, which states that there is a statistically significant difference between real rates and package rates. INA-CBGon the payment of Jamkesmas claims for inpatients at the Sukoharjo District Hospital (p-value 0.001). Agustin's research results have similarities with those of the researchers, namely that they both find differences between real hospital rates and INA-CBG's rates.

\section{Conclusion}

The difference between the real hospital rates and the INA-CBG's rates for the Caesarean section at RSU.Imelda Pekerja Indonesia in the period from March to April 2019 as many Among the 149 patients, the cost incurred by the hospital was Rp. 1,210,233,377, while the cost incurred by INA-CBG's is Rp. 928,230,740. The difference between the real hospital rates and the INA-CBG's rates is Rp. 282,002,637, the difference is negative because the total cost of services incurred by the hospital for sectio caesarean is greater than the total cost of INA-CBG's paid by BPJS Kesehatan.

Factors that influence the difference between the real hospital prices and the BPJS prices for the Sectio Caesarea at the RSU. Imelda Pekerja Indonesia are real hospital rates for medical services provided differ according to class of care such as services which include medication, medical rehabilitation, midwifery and nursing care, consultation, doctor's visite, as well as facility services such as hospital facilities, medicines and materials. operating tools and consumables. As for INA-CBC's rates, medical services are determined based on service packages based on disease diagnosis and treatment groupings.

The efforts made by the RSU. Imelda Pekerja Indonesia in covering the shortage of INA-CBG's claim costs, namelythe existence of cross subsidies obtained from the diagnosis of other diseases.

a) Providing services prioritizing quality and patient safety

b) Have a BPJS claim verification team,

c) Submission of claim files is always complete and on time,

d) RSU. Imelda, an Pekerja Indonesia, always regrets receiving a 100\% claim fee from the BPJS

\section{References}

Bungin, Burhan. 2015. Metodologi Penelitian Sosial dan Ekonomi. Edisi 1. Jakarta: Prenadamedia Group.

Depkes RI, 2012, Profil Kesehatan Indonesia Tentang BPJS.

Dumaris, Hotma. 2015. Analisis Perbedaan Tarif Rumah sakit dan Tarif INA-CBG 
Pelayanan Rawat Jalan di RSUD Budhi Asih Jakarta. http://jurnalkesmas.ui.ac.id/arsi/article/view/2209 Diakses pada tanggal 19 Januari 2019

Febriani. 2010. Analisis Perhitungan Unit Cost Pelayanan Hemodialisis http://journal.fkm.ui.ac.id. Diakses Pada Tanngal 21 Januari 2019.

Hernowo, dkk. 2018. Analis Tarif Layanan Kesehatan BPJS Kesehatan (INA-CBG) dan Efesiensi Layanan Tahun 2017(Studi Kasus Pada RS. XXX) http://repository.perbanas.id/xmlui/bitstream/handle/123456789/1687/BPJS\%20da n\%20ABC.pdf?sequence $=1$ Diakses pada tanggal 10 Agustus 2019

Kebijakan Kesehatan Indonesia. (2012). Kebijakan Pembiayaan Kesehatan, http://www. Kebijakan kesehatan Indonesia .net/337-kebijakan-pembiayaan kesehatan.

Kusumaningtyas, et all 2013. Metodologi Penelitian Pendidikan, Bumi Aksarana, Jakarta.

Laela, 2015, Tingkat Kepuasan Pasien Terhadap Pelayanan Rekam Medis Rawat Jalan Di puskesmas gamping i sleman Yogyakarta.

Notoatmodjo, 2017 ,Metodologi penelitian Kesehatan Peraturan Menteri Kesehatan Republik Indonesia Nomor 27 Tahun 2014 Tentang Petunjuk Teknis Sistem INA-CBG (Indonesian Case Based Groups). http://www.pasienbpjs.com/2016/07/mengenalINA-CBGs-standar-tarif-bpjs.html Diakses tanggal 10 Oktober 2017.

Peraturan Menteri Kesehatan Republik Indonesia Nomor 59 Tahun 2014 Tentang Standar tarif Pelayanan Kesehatan Dalam Penyelenggaran Program Jaminan Kesehatan. http://www.depkes.go.id/resources/download/peraturan/pmk-59-thn-2014- ttgstandar-tarif-jkn.pdf. Diakses pada tangal 10 Agustus 2018.

Peraturan Menteri Kesehatan Republik Indonesia Nomor 64 Tahun 2016

Tentang Standar tarif Pelayanan Kesehatan Dalam Penyelenggaran Program Jaminan Kesehatan.https://inacbg.kemkes.go.id/Rules/PMK_No._64_ttg_Standar_Tarif_Pela yanan_ Kesehatan_Dalam_Penyelenggaraan_Program_Jaminan_Kesehatan_.pdf. Diakses pada tanggal 7 September 2019

Peraturan Menteri Kesehatan Republik Indonesia Nomor 76 Tahun 2016

Tentang Pedoman Indonesian Case Base Groups (INA-CBG) dalam Pelaksanaan Jaminan Kesehatan Nasional. www.jamsosindonesia.com. Diakses pada tanggal 23 Agustus 2019.

Profil RSU Imelda Pekerja Indonesia, 2019, Medan.

Tabrany, 2008, Journal of Indonesian Public Health

Tabrany, 2014 Jaminan Kesehatan Nasional,Jakarta

Tabrany, No 71 Tahun 2013 Tentang Pelayanan Kesehatan pada JKN.

Walintukan, et all 2017, Analisis Perbedaan Tarif Riil Dengan Tarif INA-CBG's Pasien Bedah Badan Penyelenggara Jaminan Sosial Kesehatan di Rumah Sakit Gunung Maria Tomohon.

WHO, 2010. Tentang kesehatan di Indonesia.

Yui 2012. Analisis Perbedaan Tarif Riil Dengan Tarif INA-CBG's Pasien Bedah Badan Penyelenggara Jaminan Sosial (BPJS) Kesehatan Di Rumah Sakit Gunung Maria Tomohon.. 